Original Research Paper

\title{
Pendampingan Penyusunan Karya Tulis Ilmiah Bagi Guru-Guru SMA/MA di Kecamatan Narmada Lombok Barat
}

\author{
Hamidsyukrie ZM ${ }^{1}$, Syafruddin ${ }^{1}$, Muntari ${ }^{1}$ \\ ${ }^{1}$ Pascasarsarjana Universitas Mataram, Mataram, Indonesia;
}

DOI: https://doi.org/10.29303/jpmpi.v3i2.514

Sitasi : Hamidsyukrie, Z. , Syafruddin., \& Muntari. (2020). Pendampingan Penyusunan Karya Tulis Ilmiah Bagi GuruGuru Sma/MA Di Kecamatan Narmada Lombok Barat. Jurnal Pengabdian Magister Pendidikan IPA, 3(2)

\author{
Article history \\ Received: 19 September 2020 \\ Revised: 14 Oktober 2020 \\ Accepted: 19 November 2020 \\ *Corresponding Author: \\ Hamidsyukrie, \\ Universitas Mataram, Mataram, \\ Indonesia; \\ Email: \\ hamidsyukriezm@unram.ac.id
}

\begin{abstract}
Kompetensi profesional adalah satu dari empat kompetensi yang harus dimiliki oleh seorang guru. Untuk pengembangan keprofesian berkelanjutan, guru harus mampu melakukan publikasi ilmiah hasil penelitian atau gagasan dalam bidang ilmu pendidikan. Karya tulis bisa berupa laporan di antaranya hasil penelitian pendidikan, makalah ilmiah, tulisan ilmiah popular, artikel ilmiah dalam bidang pendidikan, dan buku teks pelajaran. Kegiatan pengabdian kepada masyarakat kali ini dimaksudkan agar guru memahami secara komprehensif mengenai teknik penyusunan karya ilmiah; guru terampil dalam menyusun karya tulis ilmiah untuk publikasi; dan guru bisa mempublikasikan tulisan ilmiahnya dalam jurnal ilmiah. Metode yang digunakan dalam pengabdian kepada masyarakat ini adalah melalui workshop dan pendampingan yang menekankan pada praktek yang didasarkan pada tagihan dan kebutuhan guru. Pengabdian dilaksanakan dengan tahapan sebagai berikut: studi literatur, menganalisis kebutuhan guru, pengukuran kemampuan awal guru, pelaksanaan kegiatan berupa kajian teori, praktek membuat karya tulis ilmiah untuk dipublikasikan, pemantauan dan bimbingan di lapangan, evaluasi hasil pelaksanaan pembimbingan penulisan, dan penyusunan laporan. Hasil kegiatan pendampingan menunjukkan bahwa kegiatan pendampingan penyusunan karya ilmiah sangat dibutuhkan oleh guru. Hal ini didasarkan pada pengakuan guru dan hasil evaluasi kegiatan. Selain itu, berdasarkan penilaian terhadap artikel yang disusun setelah kegiatan workshop dan pembimbingan, guru mampu membuat tulisan yang layak untuk dipublikasikan pada jurnal ilmiah nasional sehingga dapat membantu guru dalam mengembangkan kompetensi profesionalnya.
\end{abstract}

Keywords: Pendampingan, Penulisan, Penyuntingan, Karya Ilmiah

\section{Pendahuluan}

$K^{\circ}$ ompetensi profesionalisme guru merupakan hal yang penting yang harus dimiliki seorang guru. Artinya guru harus mampu melaksanakan dan mengembangkan profesinya dengan maksimal. Bagi guru yang mampu menunaikan tugas dan mengembangkan profesinya diberi penghargaan. Salah satu penghargaan yang diberikan adalah kenaikan pangkat/golongan yang diikuti dengan kenaikan gaji. Pengembangan profesi dengan kenaikan pangkat/ golongan IVa ke atas menuntut sedikitnya 12 angka kredit, namun fakta yang terjadi 
di lapangan ternyata membuat karya tulis ilmiah ini merupakan kegiatan yang tidak mudah dilakukan oleh guru, padahal membuat karya tulis ilmiah (KTI) menjadi salah satu syarat kenaikan pangkat. Dari data Badan Kepegawaian Nasional (BKN) 2005, sekitar 1,4 juta guru berstatus PNS (Chotimah, 2011) umumnya berada di pangkat III/a saapai III/d yang jumlahnya mencapai 996.926 guru. Adapun di golongan IV, ada 336.601 guru, dengan rincian golongan IV/a sebanyak 334.184 guru, golongan IV/b berjumlah 2.318 guru, golongan IV/c sebanyak 84 guru, dan golongan IV/d ada 15 guru. Membuat karya tulis ilmiah merupakan salah satu upaya yang dapat dilakukan oleh guru dalam mengembangkan profesinya, di samping karya-karya yang lain.

Menyadari akan pentingnya peranan guru dalam memajukan pendidikan nasional dan menyiapkan sumber daya manusia yang berkualitas, guru yang berkualitas di masa sekarang dan yang akan datang mutlak diperlukan. Untuk itu, pemerintah melalui Menteri Negara Pendayaan Aparatur Negara mengeluarkan Permenegpan Nomor 16 Tahun 2009 tentang jabatan angka fungsional guru dan angka kreditnya. Unsur dan sub unsur kegiatan guru yang dinilai angka kreditnya meliputi pendidikan, pembelajaran/ pembimbingan, pengembangan keprofesian berkelanjutan, dan penunjang. Pengembangan profesi berkelanjutan meliputi sub unsur pengembangan diri, publikasi ilmiah, dan karya inovatif. Publikasi ilmiah dapat meliputi publikasi ilmiah atas hasil penelitian atau gagasan inovatif pada bidang pendidikan formal dan publikasi buku teks pelajaran. Pada Pasal 16 Ayat (2) dinyatakan bahwa "Untuk kenaikan jabatan/ pangkat stingkat lebih tinggi dari guru pertama, pangkat penata muda, golongan ruang III/a sampai dengan guru utama, pangkat pembina utama, golongan ruang IV/e wajib melakukan kegiatan pengembangan keprofesian berkelanjutan yang meliputi sub unsur pengembangan diri, publikasi ilmiah, dan/atau karya inovatif."

Kegiatan ilmiah bagi guru berupa: (1) presentasi pada forum ilmiah, publikasi ilmiah atas hasil penelitian atau gagasan ilmu di bidang pendidikan formal, publikasi buku pelajaran, buku pengayaan, dan pedoman guru (Djuroto dan Suprijadi, 2003). Tingkat kerajinan guru dalam publikasi ilmiah, merupakan kriteria guru masa depan, yaitu terampil dalam menulis KTI untuk publikasi. Rajin menghasilkan karya tulis ilmiah. Menulis merupakan aktivitas melatih berpikir logis, sistematis, argumentatif, penggunaan bahasa, dan lain-lain. Semua kemampuan yang dibutuhkan dalam kegiatan menulis tersebut sangat mendukung profesi guru, baik dalam proses belajar-mengajar maupun dalam berdiskusi dan memecahkan masalah pembelajaran. Guru juga sewajarnya berfungsi sebagai pembimbing dalam pelaksanaan karya tulis ilmiah bagi siswa-siswanya. Berbagai pembaruan dalam pelaksanaan proses pembelajaran yang berintikan kemandirian dalam belajar menuntut agar siswa-siswanya mampu membuat karya ilmiah. Keterampilan tersebut tentunya sangat mendukung adanya program life skill yang tengah digalakkan di dunia pendidikan.

Kesulitan dalam proses penulisan akibat ketidakmampuan menulis guru dapat mengakibatkan frustasi yang disertai dengan perilaku bermacam-macam. Dalam kenyataannya, ada guru yang mogok menulis karena bingung apa 
yang harus dikerjakan. Dengan banyaknya dampak negatif yang dapat ditimbulkan dari kesulitan menulis, maka tampaknya persoalan ini tidak bisa dibiarkan berlarut-larut. Bagaimanapun persoalan kesulitan menulis tidak hanya berhubungan dengan pengumpulan angka kredit melalui penulisan karya ilmiah, tetapi berkaitan juga dengan kualitas proses pembelajaran di sekolah. Bisa dibayangkan bagaimana kualitas lulusan dihasilkan dalam hal menulis, apabila gurunya sendiri tidak mampu menulis.

Faktor-faktor penyebab kesulitan guru yang dikemukakan di atas masih bersifat umum. Tentu saja masih banyak faktor lain yang mungkin menghambat guru dalam menulis, misalnya: Pertama, guru kurang membaca. Kegiatan membaca dapat dikatakan sebagai faktor kunci dalam menulis. Kedua, guru kurang latihan menulis. Belajar menulis sama halnya dengan belajar berenang; kalau tidak dipraktikkan tidak akan pernah bisa berenang. Ketiga, guru kerancuan dalam berpikir. Faktor ini sering sekali terjadi sehingga tulisan kelihatan kacau dan tidak jelas alur logika yang digunakan (Djuroto dan Suprijadi, 2003).

Untuk dapat menyelesaikan masalah yang dihadapi para guru SMA/MA di Kecamatan Narmada Kabupaten Lombok Barat, maka salah satu solusinya adalah dengan cara memberikan workshop dan pendampingan pada guru-guru sekolah menengah atas yang berbasis pada praktek dan pembimbingan/pendampingan in service training bagi guru-guru SMA/MA di Kecamatan Narmada Kabupaten Lombok Barat.

\section{Metode}

1. Metode Pelaksanaan Kegiatan

Metode yang digunakan pada pengabdian ini adalah workshop dan pendampingan yang berbasis praktik penyusunan karya tulis ilmiah dengan pembimbingan intensif. Peserta diberi pemahaman tentang dasar-dasar, prinsipprinsip, dan model penulisan karya tulis ilmiah. Peserta dibekali pengetahuan penulisan ilmiah mulai dari penggunaan bahasa yang baik dan benar, penulisan kalimat topik dan pengembangan paragraph, membuat parafrase, penulisan rujukan dan kutipan, plagiarisme, kode etik penulis, sistematika dan unsur-unsur penulisan karya tulis ilmiah. Pelatihan penulisan paragraph sangat penting dalam karya tulis ilmiah (Hamidsyukrie ZM, 2003). Guru selanjutnya ditugaskan untuk memilih suatu topik dan mengembangkannya dalam bentuk karya tulis ilmiah. Setelah guru menyelesaikan penulisan, tim mereviu, mengoreksi dan mengembalikannya kepada para guru untuk diperbaiki sehingga dapat menghasilkan karya tulis ilmiah yang layak untuk dipublikasikan.

2. Solusi Pemecahan

Salah satu solusi yang ditawarkan adalah pemberian pengetahuan dan pelaksanaan workshop dan pendampingan pada guru-guru SMA/MA yang ada di Kecamatan Narmada Lombok Barat. Sebelum pelaksanaan workshop dan pendampingan, tentu saja tim pelaksana pengabdian melakukan brainstorming dengan 
para guru agar diperoleh informasi yang tepat dan komprehensif tentang kebutuhan mendesak yang diperlukan guru dalam menulis karya ilmiah. Hal ini penting dilakukan karena dengan cara ini tim pengabdian dapat memahami dan mengembangkan penulisan karya ilmiah melalui pendampingan yang intensif sehingga pada akhirnya seorang dapat menghasilkan karya tulis ilmiah yang memenuhi kriteria ilmiah.

3. Target Luaran

Target luaran kegiatan pelatihan penulisan karya ilmiah pada guru-guru ini adalah:

a. Guru mampu mengaplikasikan pengetahuan dan keterampilan dalam menyusun karya tulis ilmiah.

b. Guru mampu menyusun karya tulis ilmiah yang memenuhi standar ilmiah sehingga dapat dipublikasikan dalam jurnal ilmiah.

c. Kegiatan pengabdian ini menghasilkan karya tulis ilmiah yang dipublikasikan pada jurnal ilmiah nasional.

\section{Hasil dan Pembahasan}

1. Analisis Hasil

Kegiatan pelatihan penulisan karya ilmiah bagi guru-guru SMA/MA di Kecamatan Narmada Lombok Barat menunjukkan hasil yang baik. Hal ini diindikasikan oleh hal-hal berikut:

a. Guru-guru peserta workshop sangat antusias terhadap kegiatan pelatihan. Hal ini ditunjukan dengan keterlibatan sekolah dengan mengirim guru-guru sebagai peserta workshop. Selain itu, kepala sekolah terutama kepala sekolah SMAN 1 Narmada yang bersedia menfasilitasi pelaksanaan workshop.

b. Selama kegiatan workshop berlangsung, banyak peserta yang mengajukan pertanyaan, pandangan, permintaan bimbingan, dan harapan agar kegiatan semacam ini dapat dilanjutkan dengan pembimbingan dan pendampingan sehingga peserta dapat menghasilkan tulisan yang baik dan benar.

c. Selama kegiatan berlangsung, para peserta sangat tekun mendengarkan, mencatat, dan mengkomunikasikan kembali yang sudah disampaikan oleh tim pengabdian, serta menyampaikan hambatan yang mereka hadapi ketika menulis karya ilmiah.

d. Para peserta menyampaikan kesan, penilaian, dan pandangan bahwa kegiatan workshop dan pendampingan penulisan karya ilmiah sangat bermanfaat bagi guruguru untuk meningkatkan kompetensi akademik dan profesionalisme guru. Dalam hal ini menurut mereka, guru-guru terbantu terutama untuk kenaikan kepangkatan, karena tulisan ilmiah merupakan salah satu syarat untuk bisa diangkat ke pangkat/golongan yang lebih tinggi.

\section{Faktor Pendukung}

Ada beberapa faktor pendukung yang menentukan kesuksesan kegiatan ini. Faktorfaktor itu adalah sebagai berikut: 
a. Adanya kebutuhan guru-guru untuk diberikan pelatihan penulisan karya ilmiah.

b. Kemampuan penulisan ilmiah para guru SMA/MA yang masih kurang yang diindikasikan oleh kurangnya tulisan guru pada jurnal-jurnal ilmiah lokal /nasional.

c. Adanya keinginan para guru, kepala sekolah, dan pengawas untuk dapat menyusun tulisan ilmiah yang dapat dimuat dalam jurnal ilmiah nasional / terakreditasi nasional.

\section{Faktor Penghambat}

Faktor-faktor yang menghambat kegiatan workshop dan pendampingan adalah sebagai berikut:

a. Para peserta sulit memulai menulis karena takut salah dan sulit menemukan topiktopik yang menarik dan faktual.

b. Meskipun banyak peserta yang tampak semangat dalam mendiskusikan permasalahan yang dihadapi dalam penulisan karya ilmiah, namun ada juga yang tampak sulit mengemuka-kan permasalahannya.

\section{Kesimpulan}

Kegiatan pengabdian pada masyarakat dengan tema pendampingan penyusunan karya tulis ilmiah secara umum dianggap berhasil yang dibuktikan oleh hasil yang dicapai selama dan setelah kegiatan berlangsung, yaitu: a. Adanya semangat para peserta, kepala sekolah, dan pengawas dalam menyambut dan mengikuti kegiatan workshop.

b. Adanya kesan, pengalaman, dan pandangan para peserta bahwa kegiatan ini sangat bermanfaat bagi guru-guru terutama dalam upaya kenaikan pangkat / golongan.

c. Guru, Kepala sekolah, dan pengawas sangat mengharapkan agar kegiatan sejenis dapat dilakukan secara berkala.

\section{Ucapan Terima Kasih}

Diucapkan terima kasih kepada Universitas Mataram melalui Lembaga Penelitian dan Pengabdian Pada Masyarakat yang telah mendukung pendanaan PNBP untuk kegiatan pengabdian kemitraan Pascasarjana.

\section{Daftar Pustaka}

Chotimah, U. 2011. Karya Ilmiah sebagai Salah Satu Karya Pengembangan Profesi. Jakarta: PT. Bina Karya.

Djuroto, Totok dan Bambang Suprijadi. 2003. Menulis Artikel \& Karya Ilmiah. Bandung: Remaja Rosda Karya.

Hamidsyukrie ZM. 2003. Writing Paragraph. Mataram: FKIP Universitas Mataram.

Peraturan Pemerintah Nomor 32 Tahun 2013 tentang Standar Nasional Pendidikan.

Pemendiknas Nomor 16 Tahun 2007 tentang Standar Kualifikasi Akademik dan Kompetensi Guru.

Undang-Undang Nomor 20 Tahun 2003 tentang Sistem Pendidikan Nasional.

Undang-Undang Nomor 14 Tahun 2005 tentang Guru dan Dosen.

Universitas Negeri Malang. 2020. Pedoman Penulisan Karya Ilmiah: Skripsi, Artikel dan Makalah. Edisi keempat. Malang: Univeristas Negeri Malang 